\title{
The Modern Messiah
}

The cover illustration makes use of a cartoon satirising Oscar Wilde's 1882 American lecture tour and published in the San Francisco periodical The Wasp. Wilde makes an appearance in Chapter 10 and, like other Britons discussed in this book - including Adam Smith, Thomas Paine, Robert Owen and Herbert Spencer - his ideas were influential on both sides of the Atlantic. The way that these thinkers' ideas were transformed in the USA is of special interest to the story of individualism since, once they had been transformed, the ideas helped to shape American history. They were then re-exported to the UK and other European countries and, in this way, an American culture of individualism spread across the globe.

In a curious way, G.F. Keller's cartoon of Oscar Wilde, titled the 'Modern Messiah', exemplified the American transformation of British ideas about individualism. The kernel of truth in the portrayal of Wilde as Christ entering San Francisco on a donkey is that all Wilde had to offer to Americans was a system of beliefs. The credulous Americans pictured in the cartoon had been bowled over, or pretended to be bowled over, by what The Wasp considered an arrogant, affected and pretentious attempt to make aesthetics the focus of personal and public life. Wilde's tour took place a decade before he published his manifesto for romantic individualism - 'The Soul of Man under Socialism' (see Chapter 10) - but in The Modern Messiah we already have a satirical representation of the artistic potential of every individual. Every American - from children to portly businessmen to The Wasp's customary objects of hate, i.e. members of the San Francisco Chinese community - is sporting the sunflower which Wilde chose to symbolize his attempt to elevate human sensibility.

The most scornful element of the cartoon is perhaps Keller's insinuation - with the addition of a dollar sign to the sunflower Wilde is holding - that the great artist is himself motivated by the common-sense end of making money out of the credulous Americans. In a curious way, this trope anticipates the way that, in the next century, American capitalism was able to turn the romantic individualism of Wilde and others to its own ends. It is worth noting that the sunflowers in Keller's cartoon double as advertisements for the cigars sold by the proprietor of 
The Wasp and that Keller himself began as an illustrator of cigar boxes. Later chapters of this book explain how our enthusiasm to be artists in, and of, our own lives has been transformed into one of the key resources of neoliberalism. The book argues that the future of work and politics and particularly future trends in inequality - will be strongly influenced by the fate of this culture of individualism. 